Syntax Fusion : Jurnal Nasional Indonesia

p-ISSN: -

e-ISSN : 2775-4440

Vol. 1, No. 7, Juli 2021

\title{
HUBUNGAN ASUPAN ENERGI DAN PROTEIN DENGAN STATUS GIZI SANTRI DI PESANTREN NURUL FALAH MEULABOH TAHUN 2019
}

\author{
Saiful Fakri dan Ita Jananda \\ Sekolah Tinggi Ilmu Kesehatan Medika Teuku Umar Meulaboh \\ Email: fakri.saiful@yahoo.com, itajananda@yahoo.com
}

\begin{abstract}
Abstrak
Kebutuhan asupan remaja di pondok pesantren cendreung rendah. Hal ini karena keterbatasan makanan yang disediakan di pesantren. Karena keterbatasan serta aktifitas remaja dipesanten lebih meningkat, kebutuhan zat gizi juga meningkat dari anak sekolah biasa. Ini dibuktikan berdasarkan data Riskesdes (2013) menyatakan status gizi remaja umur 16-18 tahun mengalami peningkatan dengan prevalensi sangat kurus sebesar 1,9\%, remaja kurus 7,5\%, dan gemuk 7,3\%. Untuk mengetahui Hubungan Asupan Energi Dan Protein Dengan Status Gizi Santri Di Pesantren Nurul Falah Meulaboh Tahun 2019. Jenis penelitian ini adalah Deskriptif Analistik dengan menggunakan rancangan cross sectional. Sasaran penelitian ini adalah santri telah memiliki umur 12-15 tahun sebanyak 30 santri yang mondok Pesantren Nurul Falah Meulaboh.. Teknik pengambilan sampel yang digunakan dalam penelitian ini adalah secara purposive sampling. Hasil uji statistik menggunakan chi square pada derajat kepercayaan 95\% menunjukkan tidak terdapatnya hubungan yang signifikan antara pengetahuan ibu tentang zat gizi dengan status gizi balita yaitu dengan nilai ( $p>0,05)$. Tidak terdapat hubungan asupan energi dan asupan protein dengan status gizi pada santri di Pesantren Nurul Falah Meulaboh $p=0,068$. Diharapkan melalui penelitian ini dapat menyusun menu makanan yang seimbang dan cukup untuk meningkatkan asupan energi dan asupan protein yang bervariasi bagi remaja di pesantren.
\end{abstract}

Kata Kunci : Asupan Energi, Asupan Protein, dan Status Gizi Santri

\section{Pendahuluan}

Remaja adalah sumber daya manusia yang paling potensial dalam sebuah negara karena remaja merupakan generasi penerus bangsa (R.I. Sari, 2012). Menurut Ramadani (2005) remaja akan menjadi sumber daya manusia yang berkualitas jika sejak dini terpenuhi kebutuhan gizinya, sehingga menjadi faktor kunci dalam pembangunan suatu bangsa. Kesehatan remaja menjadi perhatian serius bagi orang tua, praktisi pendidikan, ataupun remaja itu sendiri. Remaja yang sehat adalah remaja yang produktif dan kreatif 
sesuai tahap perkembangan. Oleh sebab itu, pemahaman terhadap tumbuh kembang remaja menjadi sangat penting untuk menilai keadaan remaja.

Remaja umumnya dipandang sebagai periode kehidupan dari pubertas sampai dewasa. Tahapan tersebut dalam kehidupan tidak mudah karena merupakan masa peralihan dari masa kanak-kanak hingga dewasa. Seiring dengan meningkatnya populasi remaja di Indonesia, berdasarkan sensus penduduktahun 2000 jumlah remaja (usia 15-24 tahun)adalah 40.407.628 atau 20,08\% dari jumlah penduduk di Indonesia. Berarti sekitar seperlima penduduk indonesia adalah remaja berusia 15-24 tahun (Hidayat, 2005). Kebutuhan gizi remaja relatif besar, karena mereka masih mengalami pertumbuhan (Proverawati \& S. Asfuah, 2009). Salah satu masalah serius yang menghantui dunia kini adalah konsumsi makanan olahan. Konsumsi makanan jenis ini secara berlebihan dapat berakibat kekurangan zat gizi lain (Arisman, 2004).

Kelompok usia remaja (10-18 tahun) sangat rentan mengalami kekurangan zat gizi makro, seperti energi, karbohidrat, lemak, dan protein. Angka prevalensi gizi kurang yang sangat tinggi di Asia adalah akibat kekurangan zat gizi makro yang kronis (World Bank, 2003 ; UN-SCN, 2004). Asupan zat gizi makro adalah zat gizi yang dibutuhkan dalam jumlah besar dengan satuan gram. Zat gizimakro memiliki peran utama di dalam tubuh khususnya remaja untuk menyediakan glukosa bagi sel-sel tubuh, yang kemudian diubah menjadi energi (Irianto, 2014).

Pola makan remaja serupa dengan pola makan orang dewasa. Selera makan yang begitu besar selama masa remaja harus dipenuhi dengan makanan yang bergizi baik dan seimbang. Anak remaja yang tumbuh baik dalam lingkungan rumahnya sendiri memilih makanannya dengan bijaksana. Selanjutnya dia akan mempunyai kebiasaan yang baik. Masa remaja membutuhkan zat gizi yang lebih besar jumlahnya. Bila konsumsi zat gizi tidak ditingkatkan mungkin terjadi defesiensi. Defesiensi sumber energi dapat menyebabkan tumbuh langsing bahakan sampai kurus (Irianto, 2014).

Asupan gizi anak remaja perlu diperhatikan terutama mereka yang bersekolah dengan fasilitas asrama sehingga tidak tinggal bersama orang tua. Asupan zat gizi pada siswa yang tinggal di asrama lebih rendah dibandingkan dengan siswa yang tidak tinggal di asrama. Beranjak dari hal tersebut, penting dilakukan pengkajian tentang konsumsi siswa yang tinggal di asrama serta sistem penyelenggaraan makanan yang menyediakan makanan bagi siswa (Mukrie, 1996).

Pemenuhan gizi seimbang dipengaruhi oleh pengetahuan remaja, praktek gizi remaja yang rendah tercermin dari perilaku menyimpang dalam kebiasaan memilih makanan. Remaja yang memiliki pengetahuan gizi yang baik akan lebih mampu memilih makanan sesuai kebutuhan (Emilia, 2009 ). Pengetahuan gizi memberikan bekal pada remaja bagaimana memilih makanan yang sehat dan mengerti bahwa makanan berhubungan erat dengan gizi dan kesehatan. Remaja belum sepenuhnya matang, baik secara fisik, kognitif, dan psikososial. Dalam masa pencarian identitas ini, remaja cepat sekali terpengaruh oleh lingkungan (Arisman, 2004).

Kebutuhan asupan makanan yang terjadi pada anak remaja yang ada di pondok pesantren cenderung tidak terpenuhi. Keterbatasan makanan yang tersedia salah satu 
alasan di lingkungan pesantren menambah beban remaja untuk memenuhi kebutuhan gizi seimbang. ditambah aktivitas remaja yang lebih meningkat akan menguras tenaga, apabila kebutuhan zat gizi yang perlu di serap tidak terpenuhi maka ketidak seimbangan akan mengganggu metabolisme tubuh individu.

Beberapa masalah gizi sering dialami remaja akibat konsumsi gizi yang tidak seimbang yaitu kekurangan berat badan (underweight) dan kelebihan berat badan (overweight) (Dieny, 2014). Berdasarkan data Riskesdas (2010) status gizi remaja umur 16-18 tahun prevalensi yang sangat kurus sebesar 1,8\%, remaja kurus $7,1 \%$, dan remaja gemuk 1,4\%. Riskesdas (2013) status gizi remaja umur 16-18 tahun mengalami peningkatan dengan prevalensi sangat kurus sebesar 1,9\%, remaja Kurus 7,5\%, dan gemuk 7,3\% (Riskesdas 2013).

Dari hasil survei awal yang telah dilakukan di pesantren Nurul Falah, penyediaan makanan untuk para santri dikelola oleh pesantren sendiri. Berdasarkan pengamatan langsung pada saat istirahat anak-anak pesantren baik perempuan maupun laki-laki memiliki fisik yang lebih kecil dan terlihat lesu. Sehingga sering mengalami penurunan konsentrasi yang mengakibatkan penurunan minat belajar. Hal ini disampaikan langsung oleh beberapa siswa yang diwawancara. Atas dasar itu peneliti tertarik untuk melakukan penelitian yang berjudul "Hubungan Asupan Energi Dan Protein Dengan Status Gizi Santri Di Pesantren Nurul Falah Meulaboh Tahun 2019”.

\section{Metode Penelitian}

Jenis penelitian yang digunakan dalam penelitian ini adalah Deskriptif Analistik dengan menggunakan rancangan cross sectional. Penelitian dilakukan dengan tujuan untuk mengetahui hubungan asupan kalori dan protein dengan status gizi santri di Pesantren Nurul Falah Meulaboh Tahun 2019.

Pada kerangka konsep variabel independennya adalah Asupan Energi dan Asupan Protein. Sedangkan variabel dependennya adalah Status Gizi Santri. Berdasarkan kerangka konsep maka digambarkan dengan mengacu kepada variabel yang akan diteliti adalah sebagai berikut:

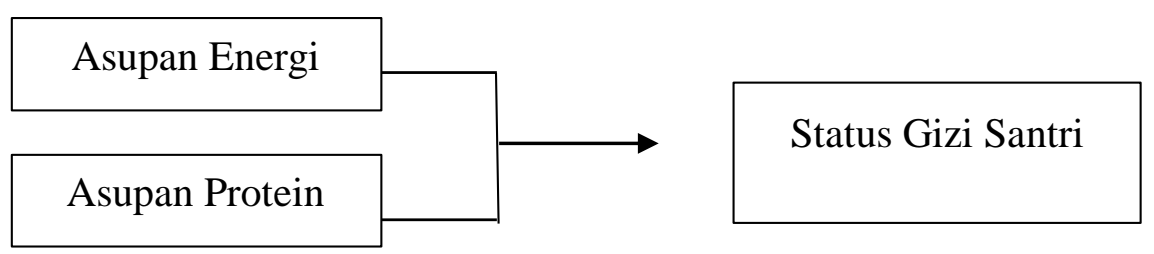

\section{Hasil dan Pembahasan}

\section{a. Pengertian Asupan Makanan}

Asupan makanan adalah makanan tunggal ataupun beragam yang dimakan seseorng dengan tujuan memenuhi kebutuhan fisiologis, psikologis, dan sosiologis 
(Wijaya Utami. R, 2010). Pemenuhan kebutuhan fisiologis berupa pemenuhan terhadap keinginan makan atau rasa lapar. Pemenuhan tujuan psikologis adalah untuk pemenuhan kepuasan emosional, sedangkan tujuan sosiologis berupa pemeliharaan hubungan manusia dalam keluarga dan masyarakat. Asupan makanan merupakan fakktor penentu dalam pemenuhan kebutuhan gizi sebagai sumber energi dan pertahanan tubuh terhadap serangan penyakit serta untuk pertumbuhan (Wijaya Utami. R, 2010).

Umumnya asupan makanan di pelajari untuk di hubungkan dengan keadaan gizi masyarakat suatu wilayah atau individu. Informasi ini dapat digunakan untuk perencanaan pendidikan gizi khususnya untuk menyusun menu atau intervensi untuk meningkatkan sumber daya manusia (SDM), mulai dari keadaan kesehatan dan gizi serta produktivitasnya. Mengetahui asupan makanan suatu kelompok masyarakat atau individu merupakan salah satu cara untuk menduga keadaan gizi kelompok masyarakat atau individu bersangkutan (Blogspot, 2017).

Secara Umum Asupan makanan adalah informasi tentang jumlah dan jenis makanan yang dimakan atau dikonsumsi oleh seseorang atau kelompok orang pada waktu tertentu. Dari asupan makanan diperoleh zat gizi esensial yang dibutuhkan tubuh untuk memelihara pertumbuhan dan kesehatan yang baik (Blogspot, 2017). Malnutrisi berhubungan dengan gangguan gizi, yang dapat diakibatkan oleh pemasukan makanan yang tidak adekuat, gangguan pencernaan atau absorbsi, atau kelebihan makan. Kekurangan gizi merupakan tipe dari malnutrisi. Asupan makan yang dikonsumsi kemudian akan menghasilkan dampak pada pertumbuhan dan perkembangan anak. Pertumbuhan anak yang dapat dilihat dari status gizinya. (Blogspot, 2017).

\section{b. Asupan Energi}

Energi diperoleh dari proses pembakaran karbohidrat, lemak, dan protein makanan. kebutuhan energi manusia di dalam tubuh akan tercukupi bila kebutuhan akan zat-zat makanan tercukupi pula (Nuraini, 2018). Energi yang masuk melalui makanan harus harus seimbang dengan kebutuhan energi seseorang. Bila hal tersebut tidak tercapai akan terjadi pergeseran keseimbangan kearah negatif atau positif. Keadaan berat badan seseorang dapat digunakan sebagai salah satu petunjuk apakah seseorang dalam keadaan seimbang, kelebihan, atau kekurangan energi. Ketidaksinambangan masukan energi dengan kebutuhan yang berlangsung jangka lama akan menimbulkan masalah kesehatan (Departemen Gizi Dan Kesehatan Masyarakat, 2007).

Mengonsumsi energi yang melebihi kecukupan akan disimpan sebagai cadangan dalam tubuh berbentuk lemak atau jaringan lain. Apabila keadaan ini berlanjut akan mengakibatkan kegemukan disertai berbagai macam penyakit degeneratif seperti hipertensi, penyakit jantung, dan DM. Kekurangan energi yang berlangsung lama akan mengakibatkan penurunan berat badan dan kekurangan zat gizi lain. Penurunan berat badan yang berlanjut akan mengalami keadaan gizi kurang. Keadaan gizi kurang akan mengakibatkan terhambatnya tumbuh kembang anak. Dan dampaknya pada saat usia dewasa, tinggi badannya kurang maksimal dan kurang tangguh. Selain itu akan mudah terkena penyakit infeksi (Depkes RI, 2003 dalam Sari. RI, 2012). 
Energi dibutuhkan remaja untuk aktifitas fisik, metabolisme organ tubuh dan mendukung pertumbuhan serta perkembangan selama puberitas. Pada usia remaja umur 10-18 tahun, terjadi proses perbumbuhan jasmani yang pesat serta perubahan bentuk dan susunan jaringan tubuh, disamping aktifitas yang juga tinggi (Brown, 2005). Menurut Arisman (2009) remaja putra memerlukan lebih banyak energi dibandingkan remaja putra. Pada usia 16 tahun remaja putra membutuhkan energi lebih besar dan menurun menjadi 2900 kkal perhari pada usia 16-19 tahun. Kebutuhan remaja putri memuncak pada usia 12 tahun kemudian menurun menjadi 2200 kkal pada usia 18 tahun. Perhitungan ini didasarkan pada stadium perkembangan fisiologis bukan usia kronologis (Sari. RI, 2012).

\section{c. Asupan Protein}

Protein selain sebagai sumber energi juga mempunyai fungsi yang tidak dapat digunakan oleh zat gizi lain, yaitu membangun serta memelihara sel-sel dan jaringan tubuh. Kekurangan protein dapat menyebabkan kwashiorkor pada anak-anak dibawah lima tahun. Protein secara berlebihan tidak menguntungkan tubuh. Makanan yang tinggi protein biasanya tinggi lemak sehingga dapat menyebabkan obesitas. Kelebihan protein dapat menyebabkan masalah dehidrasi, diare, asidosis, kenaikan ureum darah dan demam (Almatsier, 2002).

Kebutuhan protein pada remaja dipengaruhi dengan jumlah protein yang diperlukan untuk memelihara jaringan tubuh yang ada. Kebutuhan protein berhubungan dengan pertumbuhan dan perkembangan remaja. Puncak terjadinya kebutuhan protein terjadi pada saat puncak percepatan tinggi badan.

\section{Analisa Univariat}

\section{a. Umur Responden}

Tabel 4.1. Distribusi Frekuensi Umur Responden Di Pesantren Nurul Falah Meulaboh Tahun 2019

\begin{tabular}{ccc}
\hline Umur & $\mathbf{n}$ & $\mathbf{\%}$ \\
\hline $10-12$ tahun & 8 & 26,7 \\
$13-15$ tahun & 22 & 73,3 \\
\hline Total & $\mathbf{3 0}$ & $\mathbf{1 0 0}$
\end{tabular}

Distribusi umur responden di Pesantren Nurul Falah Meulaboh dapat dilihat pada tabel 4.1. dari 30 santri yang dijadikan responden, ada sebanyak 22 orang $(73,3 \%)$ yang memiliki usia 13-15 tahun.

\section{b. Jenis Kelamin Responden}

Tabel 4.2. Distribusi Frekuensi Jenis Kelamin Responden Di Pesantren Nurul Falah Meulaboh Tahun 2019

\begin{tabular}{ccc}
\hline Jenis kelamin & n & \% \\
\hline Laki-laki & 17 & 56,7
\end{tabular}




\begin{tabular}{ccc} 
Perempuan & 13 & 43,3 \\
\hline Total & $\mathbf{3 0}$ & $\mathbf{1 0 0}$ \\
\hline
\end{tabular}

Distribusi jenis kelamin responden di Pesantren Nurul Falah Meulaboh dapat dilihat pada tabel. Dari 30 santri yang dijadikan responden, ada sebanyak 17 orang $(56,7 \%)$ yang memiliki jenis kelamin laki-laki.

\section{c. Status Gizi Responden}

Tabel 4.3. Distribusi Status Gizi Responden Di Pesantren Nurul Falah Meulaboh Tahun 2019

\begin{tabular}{ccc}
\hline Status Gizi & $\mathbf{n}$ & $\mathbf{\%}$ \\
\hline Kurus & 12 & 40 \\
Normal & 17 & 56,7 \\
Obesitas & 1 & 3,3 \\
\hline Total & $\mathbf{3 0}$ & $\mathbf{1 0 0}$ \\
\hline
\end{tabular}

Distribusi status gizi responden di Pesantren Nurul Falah Meulaboh dapat dilihat pada tabel. Dari 30 santri yang dijadikan responden, ada sebanyak 17 orang responden $(56,7 \%)$ yang memiliki status gizi normal.

d. Asupan Energi

Tabel 4.4.Distribusi Asupan Energi Responden Di Pesantren Nurul Falah Meulaboh Tahun 2019

\begin{tabular}{ccc}
\hline Asupan Energi & N & \% \\
\hline Kurang & 28 & 93,3 \\
Baik & 2 & 6,7 \\
\hline Total & $\mathbf{3 0}$ & $\mathbf{1 0 0}$ \\
\hline
\end{tabular}

Distribusi asupan energi responden di Pesantren Nurul Falah Meulaboh dapat dilihat pada tabel. Dari 30 santri yang dijadikan responden, ada sebanyak 28 orang responden $(93,3 \%)$ yang memiliki asupan energi yang kurang.

e. Asupan Protein

Tabel 4.5. Distribusi Asupan Protein Responden Di Pesantren Nurul Falah Meulaboh Tahun 2019

\begin{tabular}{ccc}
\hline Asupan Protein & n & \% \\
\hline Kurang & 28 & 93,3 \\
Cukup & 2 & 6,7 \\
\hline Total & $\mathbf{3 0}$ & $\mathbf{1 0 0}$ \\
\hline
\end{tabular}


Distribusi asupan protein responden di Pesantren Nurul Falah Meulaboh dapat dilihat pada tabel. Dari 30 santri yang dijadikan responden, ada sebanyak 28 orang responden $(93,3 \%)$ yang memiliki asupan protein yang kurang.

\section{Analisa Bivariat}

Analisa bivariat untuk mengetahui hubungan variabel independen dan dependen. Pengujian ini menggunakan uji chi-square. Dimana terdapat hubungan dengan bermakna secara statistik jika diperoleh nilai $\mathrm{p}_{\text {velue }}<0,05$.

\section{a. Hubungan Asupan Energi Dengan Status Gizi Santri}

Tabel 4.6. Hubungan Asupan Energi Santri Dengan Status Gizi Santri Di Pesantren Nurul Falah Meulaboh Tahun 2019

\begin{tabular}{|c|c|c|c|c|c|c|c|c|c|}
\hline \multirow{3}{*}{$\begin{array}{c}\text { Asupan } \\
\text { Energi }\end{array}$} & \multicolumn{6}{|c|}{ Status Gizi Santri } & \multirow{2}{*}{\multicolumn{2}{|c|}{ Jumlah }} & \multirow{3}{*}{$\begin{array}{c}\text { P } \\
\text { Velue }\end{array}$} \\
\hline & \multicolumn{2}{|c|}{ Kurus } & \multicolumn{2}{|c|}{ Normal } & \multicolumn{2}{|c|}{ Obesitas } & & & \\
\hline & $\mathrm{n}$ & $\%$ & $\mathrm{~N}$ & $\%$ & $\mathrm{n}$ & $\%$ & $\mathrm{~N}$ & $\%$ & \\
\hline Kurang & 12 & 42,9 & 16 & 57,1 & 0 & 0,0 & 28 & 100 & \multirow{2}{*}{0,068} \\
\hline Cukup & 0 & 0,0 & 1 & 50,0 & 1 & 50,0 & 2 & 100 & \\
\hline Jumlah & 12 & 40,0 & 17 & 56,7 & 1 & 3,3 & 30 & 100 & \\
\hline
\end{tabular}

Dari tabel diketahui dari 2 responden yang memiliki asupan energi yang cukup dengan status gizi normal sebanyak 1 responden $(50,0 \%)$ dan yang memiliki asupan energi cukup dengan status gizi obesitas sebanyak 1 responden (50,0\%). Sedangkan dari 28 responden yang memiliki asupan energi kurang dengan status gizi normal sebanyak 16 orang $(57,1 \%)$ dan yang memiliki asupan energi kurang dengan status gizi kurus sebanyak 12 responden (42,9\%).

Dari hasil uji chi square didapat nilai $\mathrm{P}$ velue $=0,068$ dan ini lebih besar dari $\alpha=0,05\left(\mathrm{P}_{\text {velue }}=0,068>\alpha=0,05\right)$ sehingga tidak terdapat hubungan yang signifikan antara asupan energi dengan status gizi santri di Pesantren Nurul Falah Meulaboh Tahun 2019.

\section{1) Pembahasan}

Pada penelitian ini didapatkan bahwa lebih banyak siswa yang mengkonsumsi energi nya kurang dibandingkan dengan konsumsi energi yang baik ( $\geq 80 \%$ AKG). Hasil penelitian ini sejalan dengan hasil penelitian yang diperoleh Tinneke, P (2008) yang menyatakan tidak ada hubungan bermakna antara asupan energi dengan status gizi. Namun hasil ini berbeda dengan penelitian Daryono (3003) dan Mulyani (2004) yang menemukan adanya hubungan yang signifikan antara konsumsi energi dengan status gizi.

Perbedaan hasil penelitian ini dengan penelitian terdahulu kemungkinan disebabkan pada penelitian ini rata-rata konsumsi energi kurang dari $(\leq 80 \%$ AKG). Hal ini kemungkinan disebabkan oleh ketidakmampuan tubuh 
mengabsorbsi zat-zat gizi yang masuk kedalam tubuh dan adanya gangguan pencernaan. Kebutuhan energi terutama dihasilkan dari karbohidrat dan lemak. Sumber energi utama adalah karbohidrat, karena banyak terdapat di alam dan relatif murah dibandingkan protein. Jika konsumsi karbohidrat tidak mencukupi, maka kebutuhan energi akan diambil dari protein dengan mengabaikan fungsinya sebagai zat pembangun. Kekuranan energi dapat berakibat pada kurang berat badan dari berat seharusnya. Pada anak sekolah kekurangan energi dapat menghambat pertumbuhan.

\section{b. Hubungan Asupan Protein Dengan Status Gizi Santri}

Tabel 4.7. Hubungan Asupan Protein Santri Dengan Status Gizi Santri Di Pesantren Nurul Falah Meulaboh Tahun 2019

\begin{tabular}{|c|c|c|c|c|c|c|c|c|c|}
\hline \multirow{3}{*}{$\begin{array}{l}\text { Asupan } \\
\text { Protein }\end{array}$} & \multicolumn{6}{|c|}{ Status Gizi Santri } & \multirow{2}{*}{\multicolumn{2}{|c|}{ Jumlah }} & \multirow{3}{*}{ P Velue } \\
\hline & \multicolumn{2}{|c|}{ Kurus } & \multicolumn{2}{|c|}{ Normal } & \multicolumn{2}{|c|}{ Obesitas } & & & \\
\hline & $\mathrm{n}$ & $\%$ & $\mathrm{~N}$ & $\%$ & $\mathrm{n}$ & $\%$ & $\mathrm{n}$ & $\%$ & \\
\hline Kurang & 12 & 42,9 & 16 & 57,1 & 0 & 0,0 & 28 & 100 & \multirow{2}{*}{0,068} \\
\hline Cukup & 0 & 0,0 & 1 & 50,0 & 1 & 50,0 & 2 & 100 & \\
\hline Jumlah & 12 & 40,0 & 17 & 56,7 & 1 & 3,3 & 30 & 100 & \\
\hline
\end{tabular}

Dari tabel diketahui dari 2 responden yang memiliki asupan protein yang cukup dengan status gizi normal sebanyak 1 responden $(50,0 \%)$ dan yang memiliki asupan protein cukup dengan ststus gizi obesitas sebanyak 1 responden $(50,0 \%)$. Sedangkan dari 28 responden yang memiliki asupan protein kurang dengan status gizi normal sebanyak 16 orang $(57,1 \%)$ dan yang memiliki asupan protein kurang dengan status gizi kurus sebanyak 12 responden (42,9\%).

Dari hasil uji chi square didapat nilai $\mathrm{P}$ velue $=0,068$ dan ini lebih besar dari $\alpha=0,05\left(\mathrm{P}_{\text {velue }}=0,068>\alpha=0,05\right)$ sehingga tidak terdapat hubungan yang signifikan antara asupan protein dengan status gizi santri di Pesantren Nurul Falah Meulaboh Tahun 2019.

\section{1) Pembahasan}

Pada penelitian ini didapatkan bahwa lebih banyak siswa yang mengkonsumsi protein nya kurang dibandingkan dengan konsumsi protein yang baik ( $\geq 80 \%$ AKG). Hasil penelitian ini sejalan dengan hasil penelitian yang diperoleh Tinneke, P (2008) yang menyatakan tidak ada hubungan bermakna antara asupan protein dengan status gizi. Namun hasil ini berbeda dengan penelitian Daryono (3003) dan Mulyani (2004) yang menemukan adanya hubungan yang signifikan antara konsumsi protein dengan status gizi. 
Status gizi kurang lebih banyak ditemukan pada sisiwa dengan konsumsi protein $(\geq 80 \%$ AKG). Meskipun konsumsi protein akan digunakan untuk memenuhi kebutuhan energi tubuh. Hal ini sesuai dengan pendapat almatsier (2001) yang mengatakan absorbsi protein oleh karena suatu sebab mungkin tidak terjadi secara komplit. Hal ini dapat disebabkan karena struktur fisika atau kimia protein tidak dapat dicerna dan dikeluarkan melalui usus halus tanpa perubahan.

Pada anak usia sekolah, protein yang dibutuhkan harus berkualitas tinggi karena anak berada pada masa pertumbuhan. Tubuh yang menerima cukup makanan bergizi mempunyai simpanan protein yang dapat digunakan sebagai cadangan. Tetapi bila tidak mencukupi kebutuhan tubuh dan berlangsung lama, gejala-gejala kurang protein akan timbul. Dalam tubuh tidak ada penyimpanan yang sebenarnya bagi protein yang berlebihan sebagaimana halnya bagi lemak dan dalam taraf rendah untuk karbohidrat dalam bentuk glikogen. Protein merupakan zat gizi yang paling banyak dalam tubuh setelah air, jika cukup karbohidrat dan lemak dimakan untuk menutup pengeluaran energi yang meningkat, kerja dan bentuk kegiatan lain yang biasanya tidak meningkatkan kebutuhan protein dalam makanan (Almatsier, 2003)

\section{Kesimpulan}

a. Asupan energi dan asupan protein santri di Pesantren Nurul Falah Meulaboh sebagian besar memiliki asupan energi dan asupan protein yang kurang yaitu sebesar 93,3\% dari 30 santri yang dijadikan sampel.

b. Status gizi Santri di Pesantren Nurul Falah Meulaboh memiliki status gizi nornal $(56,7 \%)$, kurus $(40 \%)$ dan obesitas $(3,3)$.

c. Tidak terdapat hubungan asupan energi dan asupan protein dengan status gizi pada santri di Pesantren Nurul Falah Meulaboh $(p$ value $=0,068)$ 


\section{Bibliografi}

Almatsier, S. (2006). Penuntun Diet Edisi Baru. Jakarta: Gramedia Pustaka Almatsier, S. 2002. Prinsip Dasar Ilmu Gizi. Gramedia Pustaka Utama: Jakarta

Analisa Pemenuhan Kebutuhan Kalori Tenaga Kerja Bagian Office Pt X, Sebagai Dasar Upaya Pengadaan Kantin Rendah Lemak. Laporan Khusus. Surakarta: Program D-III Hiperkes Dan KK FK UNS.

Arisman. (2004). Gizi Daur Kehidupan: Buku Ajar Ilmu Gizi. Buku Kedokteran EGC. Jakarta

Arisman. (2007). Gizi Dalam Daur Kehidupan Buku Ajar Ilmu Gizi. Buku Kedokteran EGD. Jakarta

Brown, E.2005. Nutrition. Through The Life Cycle Second Edition : Thomson Wadsworth. USA

Departemen Gizi Dan Kesehatan Masyarakat Fakultas KESMAS UI, (2007) Gizi Dan Kesehatan Masyarakat, PT Raja Grafindo Persada

DEPKES RI., (2009). Profil Kesehatan Indonesia. Jakarta.

Himpunan Peraturan Perundang-Undangan Keselamatan Dan Kesehatan Kerja. Jakarta. Moehji, Syamin. 2002. Ilmu Gizi. Jakarta: Papas Sinar Sinanti. Novitasari, Devie. 2009.

Irianto, Dp. (2007) Panduan Gizi Lengkap Keluarga Dan Olahragawan, Andi, Yogyakarta

Rikesdes, (2013). Riset Kesehatan Dasar. Badan Penelituan Dan Pengembangan Kesehatan Republik Indinesia, Jakarta

Sanyoto, Hertog Nur. 1992. Ilmu Gizi, Zat Gizi Utama. Jakarta: Golden Terayon Press.

Sari. Ri, 2012. Fator-Faktor Yang Berhubungan Dengan Status Gizi Remaja Usia 12-15 Tahun Di Indonesia Tahun 2017. Depok. Skripsi Program Sarjana Kesehatan Masyarakat Fakultas Kesehatan Masyarakat Universitas Indonesia.

Setyaningsih, Yuliani. 2008. Gizi Kesehatan Kerja.

Suharjho. (1986). Pangan, Gizi Dan Pertanian. Penerbit UI. Jakarta

Suma'mur P.K. 1998. Hygiene Perusahaan Dan Kesehatan Kerja, CV Haji Mas

Supriasa, I Dewa N. 2001. Penilaian Status Gizi. Jakarta.: Penerbit Buku Kedokteran EGC

Tinneke, P . 2008. Faktor-Faktor Yang Mempengaruhi Status Gizi Kurang Pada Siswa SD Di 3 Kecamatan, Kabupaten Kampur Tahun 2007. FKM UI. Jakarta 